\title{
An outline of earthquake catalogues, databases and studies of historical seismicity in the Iberian Peninsula
}

Antoni Roca $\left({ }^{1}\right)$, Arancha Izquierdo $\left({ }^{2}\right)$, Carlos Sousa-Oliveira $\left({ }^{3}\right)$ and Jose-Manuel Martínez-Solares $\left({ }^{2}\right)$

${ }^{1}{ }^{1}$ Geological Survey, Institut Cartogràfic de Catalunya, Barcelona, Spain

$\left.{ }^{(}{ }^{2}\right)$ Instituto Geográfico Nacional, Madrid, Spain

$\left(^{3}\right)$ Instituto Superior Técnico, Lisboa, Portugal

\begin{abstract}
The general purpose of the present paper is to summarize the state-of-the-art of historical earthquake knowledge and research in the Iberian Peninsula, giving an account of the main references, the historical developments and the present situation of earthquake catalogues. The most representative historical works for compiling earthquake data (catalogues) up to 1985 are referred together with those of more recent investigations carried out in Spain and Portugal for the period 1985-2003. Existing databases on historical seismicity are presented, mentioning the most important achievements in relation to quality of information.
\end{abstract}

Key words historical seismicity - catalogues macroseismic data - earthquake database - Iberian Peninsula

\section{Introduction}

The knowledge of the historical evolution of catalogues is extremely important to understand the origin of modern catalogues. A detailed analysis of the ways the information contained in these catalogues is transmitted over time helps to better interpret modern catalogues and to be aware of the real problems they may hold. Muñoz and Udias (1982) gave a thorough outline of main Spain's works related to historical earthquake data compilation and listed the main catalogues produced until 1982. The most sig-

Mailing address: Dr. Antoni Roca, Geological Survey, Institut Cartografic de Catalunya, Parc de Montjuic, 08038 Barcelona, Spain; e-mail: Antoni.Roca@icc.es nificant works reported in that study are mentioned here together with some of the new publications on particular events and some new earthquake catalogues which have appeared in Spain and Portugal since then. All these works lead to a quality improvement of the knowledge of the seismicity in our study area, the Iberian Peninsula, including Spanish, Portuguese and the Mediterranean and the Atlantic islands Canaries, Balearic and the Azores - (fig. 1).

\section{Overview of historical catalogues}

The first works on seismicity of Iberia go back to mid 18th century as a consequence of the 1755 Lisbon earthquake. The great damage produced by this event in an important European town shocked the entire European society. A large amount of literature was written, including not only a number of seismic reports and studies concerning damage at different sites 


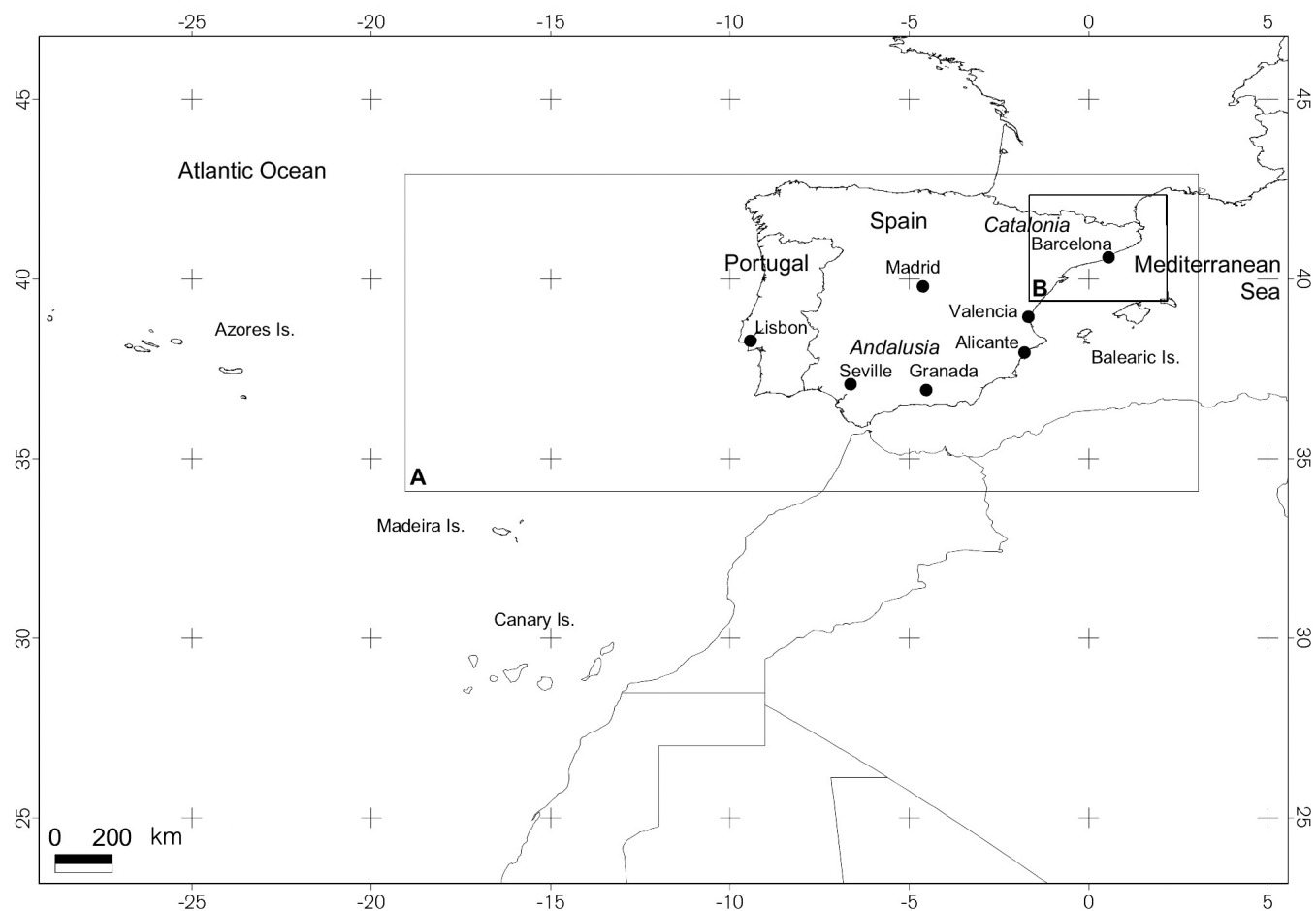

Fig. 1. Map of the Iberian Peninsula and insular territories of Spain and Portugal, with geographical names mentioned in the text. Rectangles A and B represent the areas covered by the catalogues of Martínez-Solares and Mezcua (2002) and Susagna and Goula (1999), respectively.

but also philosophical and scientific discussions, religious explanations and even poetry (Muñoz and Udias, 1982; Martínez-Solares, 2001). This earthquake can be considered the initiator of scientific interest in the compilation of seismic events in the Iberian Peninsula.

According to Muñoz and Udias (1982), the first lists of earthquakes in the Iberian Peninsula were compiled by Nipho (1755) and Roche (1756). Also, Moreira de Mendonça (1758), in his world catalogue from 1815 B.C. to 1755 A.D., containing about 400 well documented events with complete references, includes earthquakes in the Iberian Peninsula.

The work by Perrey (1847) is an important reference catalogue in Iberia, being the basis of many later studies. For earthquakes in Southern Spain, the catalogue by Taramelli and Mercalli (1886), as part of a field study on the 25 De- cember 1884 earthquake, an outstanding example of early seismological work, completed the information contained in Perrey's catalogue adding other sources. For earthquakes in NE Spain, Teixidor Cros (1884) gives a summary of the earthquake history of Catalonia, which mainly relies on a booklet from Bolós (1841) about the Olot volcanic area. Mengel (1908; 1909 ; 1929) deals with seismic data for Catalonia (both Spain's and France's) and Pyrenees region. This is a reference work for Catalonia although the author is not very critical about historical sources.

Sánchez Navarro-Neumann (1917, 1920) published a catalogue for Spain including data from different sources, mainly from previous catalogues.

One of the most valuable references for seismicity of the Iberian Peninsula is the cata- 
logue from Galbis $(1932 ; 1940)$. It is a catalogue (1032 B.C.-1933 A.D.) which uses a large amount of historical sources, giving the corresponding references, including the works from contemporary Spanish seismologists such as Rey Pastor, Sánchez Navarro-Neumann, Faura i Sans and Fontseré, among others. Munuera (1963) in his catalogue, in table format, presents basically the information from Galbis with some modifications, removing some events considered not sufficiently supported by data.

Fontseré and Iglesias (1971) is the essential reference catalogue for Catalan speaking areas: both Spanish and French Catalonia, Valencia and the Balearic Islands. It contains historical data from 1100 to 1906 A.D. based on well-reported references.

In Portugal, besides the already mentioned pioneer work by Moreira de Mendonça (1758), the most important studies on earthquake compilations prior to 1980 were produced in the early 20th century, based on data gathered in various types of publications. For example, in relation to the Azores Archipelago, mention should be made of Arquivo dos Açores (re-edition 1981-1986) and to Frutuoso (re-edition 1998 of the 16th century work). The work of Pereira de Sousa (1919), dedicated essentially to the 1755 Lisbon earthquake, is a piece of documentation of major importance. It also refers to earthquakes in the past. Choffat and Bensaude (1912) made a notable description of the 23 April 1909 Benavente earthquake in the Lower Tagus Valley, Lisbon and of the large amount of aftershocks. Miranda (1930) made an account of all felt events in Portugal in the 1920's.

But the greatest contributions to the historical earthquake compilation in Portugal were made during the commemoration of the 2nd centennial of the 1755 earthquake in the «Simpósio sobre a Acção dos Sismos». Ferreira (1955) and Agostinho (1955) presented collections of important earthquakes in the Mainland and in the Azores, respectively.

In the early 1980's, some revisions of earthquake data in the Iberian Peninsula were carried out. Among others, mention should be made of the work by Rodríguez de la Torre (1980) on the seismicity of Alicante up to the 18th centu- ry, the parametric catalogue by Suriñach and Roca (1982) for Catalonia and Pyrenees which includes a collection of isoseismal maps published in different works, the parametric catalogue by Monge (1981) on earthquakes in the Canary Islands; an extensive study by Bisbal (1984) for the Valencia region, and the study by Gentil and Justo (1983) for the region of Seville with data related to the Arab period in South Spain together with other works on Andalusian earthquakes by these same authors.

Mezcua (1982) published a catalogue of isoseismal maps for earthquakes in the Iberian Peninsula and, one year later, a parametric catalogue from the Instituto Geográfico Nacional (IGN) for the Ibero-Magreb region (Mezcua and Martínez-Solares, 1983) was completed.

In Portugal, various studies on historical seismicity were carried out in the first half of the 1980 decade. A catalogue of earthquakes in Mainland Portugal was published by Moreira (1984) and reviewed later (Moreira, 1991).

In Iberia, macroseismic data are compiled by various institutions and published on a routine basis in monthly and annual bulletins. Since 1907 the Fabra Observatory in Barcelona has carried out macroseismic surveys for all events felt in Catalonia. From 1984 this task has been undertaken in collaboration with the Servei Geològic de Catalunya - at present as part of the Institut Cartogràfic de Catalunya (ICC). Starting in 1909, the IGN obtained macroseismic data for earthquakes in Spain. In Portugal, since 1947, the Instituto Nacional de Meteorologia e Geofísica (former Serviço Meteorológico Nacional) has been responsible for macroseismic surveys. For the Azores, in 1998, they started carrying out these tasks in collaboration with the University of Azores (consortium SIVISA).

\section{Recent studies and modern catalogues (1985-2003)}

In the late 1980's there was an important development on the studies of historical seismicity by the establishment of teams of historians and seismologists working together in a more systematic way. Some EC funded projects as for example RHISE (Review of Historical 
Seismicity in Europe - 1988-1991) and BEECD (A Basic European Earthquake Catalogue and Database for the evaluation of long term seismicity and seismic hazard - 1995-1997) were of special interest for increasing international collaboration. Within the framework of these two projects efforts were devoted to comparing methodologies used by European investigators of historical seismology and establishing common principles and criteria for cataloguing seismic events, respectively (Stucchi, 1993; Albini and Moroni, 1994; Albini and Stucchi, 1997).

The major problems encountered when historical earthquakes are reviewed are related to: (i) the reliability and insufficiency of the documentary sources; (ii) errors in the transmission of the information through not-independent sources; (iii) difficulties in assessing the characteristics, typologies and, consequently, the vulnerability classes of damaged buildings; (iv) difficulties in assigning damage descriptions to individual events in earthquake sequences; (v) lack of information on damage to the complete building stock when sources report only on one or a few specific buildings like, for instance, churches or royal buildings; and (vi) problems related to the identification of toponyms and to misinterpretations of the calendar.

Examples of the concern for reliability and quality of macroseismic data in Iberia can be found in Olivera et al. (1994; 1999), Paula and Oliveira (1996), Susagna et al. (2001), among others. Several studies on particular events, earthquake series or specific time windows have been published in the last decade. Examples of these studies are as follows: Olivera $e t$ al. (1994; 1999) and Salicrú (1995) studied historical earthquakes in Catalonia; Espinar (1994) and Espinar et al. (1994) investigated historical sources for earthquakes in South Spain and also Muñoz and Udías (1991) studied a few large events in the same region; Cruz et al. (1996) initiated studies on historical seismicity in Mainland Portugal until the end of 17th century, criticising and analysing the sources of information. Most of these recent studies on historical seismicity use the technique of family trees to analyse the traceability of the sources, detecting repetition of sources not contemporary with the event.
Another topic related to the improvement of knowledge of historical earthquakes from the first half of the 20th century is the processing of early instrumental records using modern digitising techniques. This information can complement the available data obtained from the analysis of contemporary macroseismic surveys (Susagna et al., 1993). Very good records on paper support have been carefully kept in the archives of early observatories and attempts are being made to digitise and to process available records (Batlló et al., 1997; Badal et al., 2000). This type of investigation has been important to calibrate, for instance, the magnitude of the Benavente earthquake of 23 April 1909 in the Lower Tagus Valley, Lisbon (Dineva et al., 2002). A catalogue of digital historical seismograms recorded on the Wiechert seismograph of the Toledo Observatory between 1912 and 1962 was published by Samardjieva et al. (1997). An ongoing project of the IGN consists of digitising all the available records existing in its observatories for earthquakes of magnitude equal to or larger than 4.5 which occurred until 1962.

The following sections present, as a matter of illustration, a brief review of recent studies in Portugal, and of two Spanish catalogues, one for Catalonia and the other for the entire Iberian Peninsula. In addition to these studies, a few other works on revisions of earthquake data have been carried out. Among others, we should mention Rodríguez de la Torre (1990), who studied the seismicity of Iberia in the 19th century through an intensive work in newspaper archives and other sources, producing a revised catalogue from 1850 to 1900; Muñiz Gómez (2001) who, based on the works by Rodríguez de la Torre (1990), extended the historical research in Galicia (NW Spain) for the 19th and 20th centuries also through the analysis of newspapers; and various historical studies in Andalusia based on the analysis of Spanish-Arabic documentary sources, as the work by Bretón and Espinar (1996).

\section{Recent revisions in Portugal}

In early 1980, a Working Group to study historical earthquakes and produce a National Catalogue was launched by the Gabinete de Pro- 
tecção e Segurança Nuclear, Secretaria de Estado do Ambiente e dos Recursos Naturais, involving the participation of several institutions (Faculdade de Ciências, Universidade de Lisboa, Universidade Nova de Lisboa, Laboratório Nacional de Engenharia Civil, Electricidade de Portugal, Instituto Geológico e Mineiro) under the presidency of the Instituto de Meteorologia. Several studies were conducted by the Department of History of Universidade Nova de Lisboa which compiled an enormous amount of information on sources of earthquakes.

Among these works mention can be made of the monographs on revisions of historical seismicity in the 17th and 18th centuries (Wagner, 1993; Wagner et al., 1993), and in the 16th century (Henriques et al., 1988). At the Instituto de Meteorología efforts were made to compile and analyse the historical seismicity, such as the work by Moreira et al. (1993), reviewing the historical seismicity in the Gulf of Cadiz area before 1 November 1755 earthquake. As mentioned before, Moreira (1991) made an overview of seismicity in Portugal and Cruz et al. (1996) initiated studies on historical seismicity in Mainland Portugal until the end of 17th century.

Besides the «Anuário Sismológico» published since 1947, studies have been performed to compile information from different sources. Two examples from late 1980 - early 1990 are the catalogues by Martins and Mendes-Victor (1989) and Sousa et al. (1992). To quantify earthquake parameters from macroseismic information, Oliveira and Sousa (1991) made a first contribution to reduce subjectivity in treatment of historical data by introducing the concept of quality factor when analysing the large earthquake events in the Lower Tagus River. Paula and Oliveira (1996) revised all data from the «Anuário Sismológico», transformed the information in the earlier EMS-92 scale and applied a quality factor for a better definition of macroseismic intensity.

The Instituto de Meteorologia is preparing a catalogue, to be published possibly in 2004, of all earthquakes between 1980 and 2000, including macroseismic events.

For the Azores, several recent studies have been produced in relation to macroseismic catalogues. Among them, reference should be made to the work of Nunes Costa (1986) who recently compiled historical events for the Archipelago and to Silveira (2002) which made a contribution on historical seismicity for the evaluation of the hazard in San Miguel Island. Sousa and Martins (2000) made a comparison between the seismic parameters of important events from different catalogues for the Azores (Portuguese and international) and produced a first version catalogue used for hazard studies in the region. Nunes et al. $(2003 ; 2004)$ have revised many documents and compiled a large amount of information; besides analysing the elements contained in the "Anuário Sismológico» and in the work of Nunes (1986), they mention a large amount of historical references transcribing the original texts. They gathered the documentary sources from the authors who dedicated most of their lives to the history of the Azores and also revised the information contained in newspapers.

\section{A macroseismic catalogue for Catalonia (NE Spain)}

An example of a catalogue compiled according to modern criteria, in particular those established within the above mentioned BEECD project (Albini and Stucchi, 1997; http://emidius.mi. ingv.it/BEECD) is the one by Susagna and Goula (1999) for Catalonia. The geographical area covered is a rectangle in NE Iberia between Longitude $0^{\circ} 20^{\prime} \mathrm{W}$ to $3^{\circ} 30^{\prime} \mathrm{E}$ and Latitude $40^{\circ} \mathrm{N}$ to $43^{\circ} 30^{\prime} \mathrm{N}$ (fig. 1). It covers Catalonia and surroundings, in particular the Central and Eastern Pyrenees region, both Spanish and French parts. This Catalogue is part of a project of the Institut Cartogràfic de Catalunya for assessing earthquake hazard, vulnerability and risk.

This Catalogue, which is based on macroseismic data, is the result of a long process (Susagna et al., 2001) that includes: i) consideration of the existing earthquake compilations, representing the most significant information sources; ii) incorporation of the results from the studies carried out in recent years referring to the historical earthquakes; iii) re-assessment of the macroseismic questionnaires corresponding to the earthquakes during the 20th century, and 
iv) construction of a database which facilitated the critical comparison between the different sources. One of the results is a homogeneous parametric catalogue, which comprehensively represents all the available seismic information for the region under study.

An epicentre quality index and an intensity quality are given for each event together with the common macroseismic parameters; the number of macroseismic observations used for the focal parameters assessment is also reported.

The Catalogue contains 918 individual records, one for each catalogued event. Out of them, 306 records correspond to events before 1900; 612 correspond to events after 1900; and 58 earthquakes, considered in former compilations as real events, have been qualified as false or doubtful. Out of the remaining 860 earthquakes, 258 events do not have assigned intensity due to the lack of sufficient information.

The most interesting part of the Catalogue is the individual information for each earthquake, which shows the value of the parameters chosen from the aforementioned analysis. A map with all intensity data point information is also included for a total of 109 earthquakes. As a synthesis, the Catalogue includes several maps of epicentres, in particular one with the known earthquakes that have caused damage throughout history (intensity equal to or above VII MSK) and another with all events of intensity equal to or above $\mathrm{V}$ which occurred in the 20 th century.

\section{A new earthquake catalogue for the Iberian Peninsula}

The recently published new catalogue by Martínez-Solares and Mezcua (2002) constitutes a revision of the former catalogue from the Instituto Geográfico Nacional (IGN) by Mezcua and Martínez-Solares (1983) for the region inside the rectangle $\mathrm{A}$ in fig. 1.

According to the authors of this catalogue, in the time interval between the publication of these two catalogues - 20 years - problems in several records had been detected, mainly duplications, fake earthquakes, errors in epicentre locations and inaccurate intensity assessments together with lack of available references for some catalogued events. For the revision of the Catalogue, an evaluation of each one of the entries has been undertaken through an analysis of all the available documents in the IGN archive which contains published studies, internal reports, copies of contemporary sources, etc. Each document was referenced with a number, which was included in the earthquake database. All available data for each earthquake were then analysed and the corresponding parameters and quality factors for the epicentral intensity and location assigned.

A code explaining the modifications in the different parameters in this catalogue with respect to the former Mezcua and Martínez-Solares (1983) is given. For each catalogued event the number of data points with macroseismic information is indicated together with the bibliographic references.

The catalogue includes tables and maps showing intensity data points for the earthquakes with epicentral intensity equal to or greater than VIII (EMS 98) or for those with at least 15 data points available. The equivalent moment magnitude is computed following the Bakun and Wentworth (1997) methodology.

A comparison of the number of entries between this new catalogue and that of 1983 is shown in fig. 2. On the one hand, there is an increase in the number of events of low intensity, due to the inclusion in the catalogue of detailed studies such as those mentioned for the 19th and 20th century by Rodríguez de la Torre. On the other hand, some of the largest events decreased the value of $I_{o}$ as a result of intensity reevaluations.

\section{Earthquake databases}

Several attempts to provide the scientific community with data easily accessible through organised databases have been made by various institutions in Spain and Portugal, but up to now most of these projects have not been completed and databases are essentially working systems mostly for internal use in seismological centres.

The Instituto Geográfico Nacional (IGN) maintains various computer files organised with 


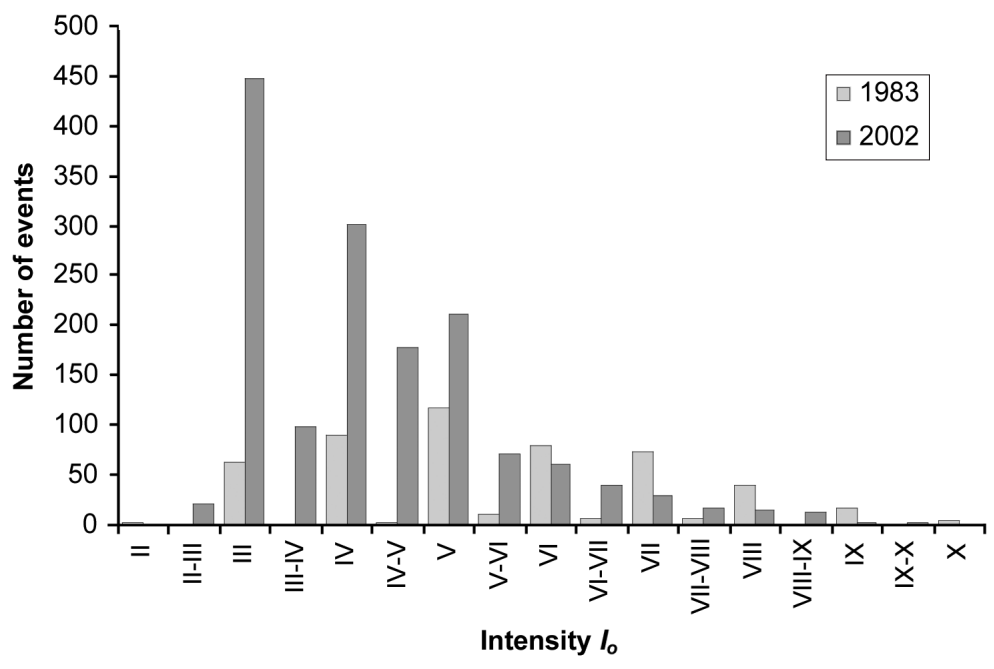

Fig. 2. Comparison of the number of events for each intensity class contained in the catalogues of Mezcua and Martínez-Solares (1983) and Martínez-Solares and Mezcua (2002) for the period 1000-1900.

database structures. The historical earthquake data available in digital form are:

- earthquakes parametric file;

- bibliography, references;

- tsunamis on the Spain's coast;

- tistorical instruments;

- some macroseismic questionnaires.

Some digital seismic cartography is also contained in the IGN digital archives: geo-referenced isoseismal maps from Mezcua (1982) and maps with geo-referenced macroseismic information as given in the recent catalogue from Martinez Solares and Mezcua (2002). Works to establish a more complete database with all the available macroseismic information are currently being carried out.

The Instituto Andaluz de Geofísica y Prevención de Desastres Sísmicos has in operation a database of historical earthquakes in Andalucia (South Spain) which includes parametric data, macroseismic information and isoseismal maps (Feriche and Botari, 2002).

The Institut Cartogràfic de Catalunya has a database with the intensity data points of all the earthquakes in the area of the catalogue from Susagna and Goula (1999). A computer file with the catalogue parametric data is available from the ICC web site (http://www.icc.es).

Nunes et al. (2004) prepared a database with the available information on Azores earthquakes for the period 1850-1998, and published it on a CD-ROM. Simões (2004) is now preparing the first Internet version of a catalogue of the Portuguese earthquakes.

\section{Final remarks}

It can be considered that the history of earthquake catalogues in the Iberian Peninsula starts with the occurrence of the 1755 Lisbon earthquake. Since then, many authors have been involved in the collection and analysis of past earthquakes. In this paper, the leading works have been presented and the main references given.

Efforts have been made in the recent decades to review the macroseismic information and to improve earthquake catalogues. However, there is still a need to carry out studies on specific historical earthquakes and to take some of the existing - published and un- 
published - works, review them under modern acknowledged procedures, that is, through an objective classification and analysis of reliability of sources, and a well-stated and justified methodology for interpreting historical data.

There is also a need to establish current policies to incorporate the validated research works into the national catalogues and databases. Very often the period of time between the publication of new research works on historical earthquakes and the corresponding changes in the institutional databases - through a necessary validation process - is too long.

Given the unquestionable importance of observed intensities for attenuation studies which are crucial for earthquake hazard and risk assessment, databases with intensity data points should be constructed and made available to the technical and scientific communities.

Many earthquakes take place on border areas and thus, for these regions a transnational collaboration is clearly needed. It would be desirable to increase this collaboration at European level with Northern Africa countries in order to go towards a cooperative Euro-Mediterranean database.

\section{Acknowledgements}

The authors want to thank Teresa Susagna and Jorge Fleta for their help in the preparation of this paper and also one anonymous reviewer for his/her comments.

\section{REFERENCES}

Agostinho, J. (1955): Relato da sismicidade dos Açores e história sísmica do arquipélago com vista principalmente à delimitação das zonas onde são de aconselhar maiores precauções anti-sísmicas nas construções, Boletim da Ordem dos Engenheiros, 4 (21), Memória 108, 1-4.

Albini, P. and A. Moroni (Editors) (1994): Historical Investigation of European Earthquakes, Materials of the CEC Project «Review of Historical Seismicity in Europe»(CNR, Milano), vol. 2, pp. 254.

AlbinI, P. and M. STUCCHI (1997): A basic European Earthquake Catalogue for the evaluation of long-term seismicity and seismic hazard (BEECD), in Seismic Risk in the European Union, edited by A. GHAZI and M. YEROYANI (Brussels-Luxembourg), vol. I, 53-77.

Arquivo dos Açores (1981-1986), edited by E. DO CANTO and F. Afonso Chaves (Edição de Instituto Universitário dos Açores e Universidade dos Açores, Ponta Delgada), vols. I to XIV (re-edition).

Badal, J., E. Samardjieva and G. Payo (2000): Moment magnitude for early (1923-1961) instrumental Iberian earthquakes, Bull. Seismol. Soc. Am., 90, 1161-1173.

BAKUN, W.H. and C.M. WENTWORTH (1997): Estimating earthquake location and magnitude from seismic intensity data, Bull. Seismol. Soc. Am., 87, 1502-1521.

Batlló, J., T. Susagna and A. Roca (1997): A processing system for old records of regional eathquakes: Analysis of the 19th November 1923 earthquake in the Pyrenees, Cahiers du Centre Européen de Geodynamique et de Séismologie, Luxembourg, 13, 149-157.

Bisbal, L. (1984): Estudio de la distribución de intensidades sísmicas en el ámbito valenciano. Su incidencia en las obras públicas, Ph.D. Thesis (Universidad Politécnica de Valencia), 9 vols.

Bolós, F. (1841): Noticia de los extinguidos volcanes de Olot y de sus inmediaciones hasta Amer, y de los nuevamente descubiertos, todos en la provincia de Gerona, Barcelona.

BRETón, M. and M. EsPINAR (1996): Fenomenos sísmicos que afectaron a las tierras andaluzas en los siglos IX al XII según las crónicas musulmanas, in Homenaje en Honor al Profesor Fernando Miguel Martínez, Universidad de Granada, 47-76.

Choffat, P. and A. Bensaude (1912): Estudos sobre o sismo do Ribatejo de 23 de Abril de 1909, Comissão do Serviço Geológico de Portugal (Imprensa Nacional, Lisboa).

CruZ, J., C.S. Oliveira and M.L. Senos (1996): Studies on historical seismicity in mainland Portugal until the end of XVII century: critical analysis of the sources, in Proceedings XXV General Assembly, European Seismological Commission, Reykjavík, W6.09.

Dineva, S., J. BATLló, D. MHHaYlov and T. VAN ECK (2002): Source parameters of four strong earthquakes in Bulgaria and Portugal at the beginning of the 20th century, J. Seismol., 6 (1), 99-123.

ESPINAR, M. (1994): Los estudios de sismicidad histórica en Andalucía: los terremotos históricos de la provincia de Almería, in El Estudio de los Terremotos en Almería (Instituto de Estudios Almerienses, Almeria), 115-180.

EsPINAR, M., J.J. QuESADA and J.D. MoRCILlo (1994): Terremotos en Granada (siglos XV-XVI). Edificación y sismicidad (Arraez Editores, Almería), pp. 108

Feriche, M. and C. Botari (2002): Base de datos de sismos históricos, in Primer Centenario del Observatorio de Cartuja. Resúmenes del Congreso Cien años de Sismología en Granada, Universidad de Granada (CDROM).

FERREIRA, H.A. (1955): Macrosismos sentidos em Portugal no período 1901-1954, Boletim da Ordem dos Engenheiros, 5 (1), Memória 128, 1-10.

FONTESERÈ, E. and J. IGLESIAS (1971): Recopilació de Dades Sísmiques de les Terres Catalanes Entre $1100 i$ 1906 (Fundació Salvador Vives Casajuana, Barcelona), pp. 547.

Frutuoso, G. (1998): Saudades da Terra, edited by Instituto Cultural de Ponta Delgada, I-VI, (re-edition).

GALBIS, J. (1932): Catálogo sísmico de la zona compreendida entre los meridianos $5^{\circ} \mathrm{E}$ y $20^{\circ} \mathrm{W}$ de Greenwich y 
los paralelos $45^{\circ} \mathrm{N}$ y $25^{\circ} \mathrm{N}$ (Dirección General del Instituto Geográfico, Catastral y de Estadística, Madrid), Tomo I , pp. 807

Galbis, J. (1940): Catálogo sísmico de la zona compreendida entre los meridianos $5^{\circ} \mathrm{E}$ y $20^{\circ} \mathrm{W}$ de Greenwich y los paralelos $45^{\circ} \mathrm{N}$ y $25^{\circ} \mathrm{N}$ (Instituto Geográfico y Catastral, Madrid), Tomo II, pp. 277

GENTIL, P. and J.L. Justo (1983): Los terramotos que afectaron a Sevilla durante la dominación árabe, in Seminario sobre Sismicidad y Riesgo Sísmico (area IberoMoghrebí), Córdoba (Publicación Instituto Geografico Nacional, Madrid), 41-50.

Henrigues, M.C., M.T. Mouzinho and N.M. Ferrão (1988): Sismicidade de Portugal: o sismo de 26 de Janeiro de 1531 (Comissão para o Catálogo Sísmico Nacional, Lisbon).

MARTínEZ-SolARES, J.M. (2001): Los efectos en España del terremoto de Lisboa (1 Noviembre 1755), Monografía No. 19, Instituto Geográfico Nacional, Madrid, pp. 756

Martínez-Solares, J.M. and J. Mézcua (2002): Catálogo Sísmico de la Península Ibérica (880 B.C.-1900 A.D.), Monografía No. 18, Instituto Geográfico Nacional, Madrid, pp. 253

Martins, I. and L.A. Mendes-Victor (1989): Catálogo Sísmico de Portugal, Monografía, Instituto Geofísico Infante D. Luis, Universidade de Lisboa.

Mengel, O. (1908): Aperçu sur la tectonique et la sismicité des Pays Catalans, in Comptes Rendus de l'Association Française pour l'Avancement des Sciences, Congrés de Clermont-Ferrand, pp. 13

Mengel, O. (1909): Monographie des terratremols de la Region Catalane, Bulletin de la Societé Ramond, Bagnéres-de-Bigorre, 66-68.

Mengel, O. (1929): Étude de la sismotectonique des Pyrénées et des Alpes Occidentales. U.G.G. Int., Annales de Sismologie, Ser. B, Fasc. 3, 3-74.

MezcuA, J. (1982): Catálogo general de isosistas de la Península Ibérica, Instituto Geográfico Nacional, Madrid. Publ. 202, pp. 322

Mezcua, J. and J.M. Martinez-Solares (1983): Sismicidad del área Iberomogrebí, Instituto Geográfico Nacional, Madrid, Publ. 203, pp. 301.

Monge, F. (1981): Catálogo sísmico preliminar del Archipiélago Canario, Cátedra de Geofísica, Universidad Complutense, Madrid, Publ. 165.

Miranda, R. (1930): Tremores de terra em Portugal (Instituto de Geofísica da Universidade de Coimbra).

Moreira de MEndonçA, J.J. (1758): Historia Universal dos Terremotos que tem havido no mundo, de que ha noticia, desde a sua creacao ate o seculo presente. Com unanarraçam individual do Terremoto do primeiro de Novembro de 1755, e noticia verdadera dos seus effeitos em Lisboa, todo Portugal, algarves, mais partes da Europa, Africa, e America, aonde se estendeu: e huma Disertaçao Physica sobre as causas geraes dos Terremotos, seus effeitos, differenças, Prognosticos e as particulares do ultimo, Offic. Antonio V. de Silva, Lisboa, pp. 272

Moreira, V.S. (1984): Sismicidade histórica de Portugal Continental, Revista do Instituto Nacional de Meteorologia e Geofísica, Lisboa, pp. 79

Moreira, V.S. (1991): Sismicidade histórica de Portugal Continental (Instituto Nacional de Meteorologia e Ge- ofísica, Lisboa), 2nd edition.

Moreira, V.S., J.S. MARQuES, J.F. CruZ and Nunes J.CosTA (1993): Review of the historical seismicity in the Gulf of Cadiz area before the 1 November 1755 earthquake. An intermediate report, in Historical Investigation of European Earthquakes, Materials of the CEC Project "Review of Historical Seismicity in Europe», edited by M. STUCCHI (CNR, Milano), vol. 1, 225-236.

MunuerA, J.M. (1963): A study of seismicity on the Peninsula Iberica area, Technical Note no. 1 «Seismic Data». Instituto Geográfico y Catastral, Madrid, pp. 93

MuÑIz Gómez, S. (2001): Revisión del Catálogo Sísmico Gallego, in Proceedings II Congreso Iberoamericano de Ingeniería Sísmica, Asociación Española de Ingeniería Sísmica, Madrid (CD-ROM).

MuÑoz, D. and A. UdíAs (1982): Historical development of Spain's catalogues of earthquakes, Bull. Seismol. Soc. Am., 72 (3), 1039-1042.

MuÑOZ, D. and A. UdíAS (1991): Three large historical earthquakes in Southern Spain, in Seismicity, Seismotectonics and Seismic Risk of the Ibero-Maghrebian Region, edited by J. Mezcua and A. Udias, Publ. Instituto Geográfico Nacional, Madrid, Ser. Monogr. No. 8, 175-182.

NIPHO, F.M. (1755): Explicación physica y moral de las causas, deñales, diferencias y efectos de los terremotos, con una relación muy exacta de los más formidables y ruinosos que ha padecido la tierra desde el principio del Mundo, hasta el que se ha experimentado en España y Portugal el día primero de Noviembre de este año 1755 , Biblioteca Nacional, Madrid, Ref. R/34858, pp. 54

Nunes Costa, J. (1986): Sismicidade Histórica e Instrumental do Arquipélago dos Açores. Catálogo preliminar: 1444-1980, Report IM/Univ.Açores/LNEC for Estudo do Hospital de Ponta Delgada.

Nunes, J.C., V.H. ForJaZ and C.S.OliveIRA (2003): Catálogo Sísmico da Região dos Acores, I (1500-1980), II (1981-1998) (Project PPERCAS, Universidade dos Açores), (in press).

Nunes, J.C., V.H. Forjaz and C S. Oluveira (2004): Catálogo Sísmico da Região dos Açores, versão 1.0 (18501998), in Proceedings Sísmica 2004, Universidade de Minho, Guimarães, Abril 2004 (CD-ROM.)

Olivera, C., E. Redondo, A. Riera, J. Lambert and A. RocA (1999): Problems in assessing focal parameters to earthquake sequences from historical investigation: the 1427 earthquakes in Catalonia, in Proceedings I Asamblea Hispano-Portuguesa de Geodesia y Geofísica (CD-ROM). Symposium Ibero Maghrebian historical and instrumental seismicity, SIM2-7, 1-8.

Olivera, C., A. Riera, J. LAmbert, E. Banda and P. AlEXANDRE (1994): Els terratrèmols de l'any 1373 al Pirineu: Efectes a Espanya i França, Servei Geològic de Catalunya, Generalitat de Catalunya, Monogr. No. 3 , pp. 320

OliveIRA, C.S. and M.L. SousA (1991): A contribution to reduce subjectivity in treatment of historical data, in Seismicity, Seismotectonics and Seismic risk of the Ibero-Maghrebian Region, edited by J. MezcuA and A. Udias, Publ. Instituto Geográfico Nacional, Madrid, Ser. Monogr. No. 8, 97-114.

Paula, A. and C.S. Oliveira (1996): Evaluation of 19471993 macroseismic information in Portugal using the 
EMS-92 scale, Ann. Geof., XXXIX (5), 989-1003.

Pereira de Sousa, F.L. (1919): O Terremoto do $1^{\circ}$ de Novembro de 1755 em Portugal, um Estudo Demográfico (Serviços Geológicos de Portugal), I-VI.

Perrey, A. (1847): Sur les tremblements de terre de la Péninsule Ibérique, Annales des Sciences Physiques et Naturelles, d'Agriculture et d'Industrie, Lyon, X, 461513.

RodRíGUEZ DE LA ToRRE, F. (1980): Catálogo sísmico de la actual provincia de Alicante (hasta final del siglo XVIII, Revista del Instituto de Estudios Alicantinos, 30, 107-133.

RODRÍGUEZ DE LA TORRE, F. (1990): Sismologia y Sismicidad en la Península Ibérica Durante el Siglo XIX, Ph.D. Thesis (Universidad de Barcelona), 5 vols..

Roche, J.L. (1756): Relacion y observaciones physicasmathematicas, y morales sobre el general terremoto, y la irrupcion del mar del dia primero de Noviembre de este año de 1755, que comprehendio a la Ciudad, y Gran Puerto de Sta. Maria, y a toda la costa, y tierra firme del Reyno de Andalucía, Imprenta de la Casa Real de las Cadenas, Puerto de Santa María, Instituto Geológico y Minero, Ref. 454-20, pp. 55

SALICRÚ, R. (1995): The 1448 earthquake in Catalonia. Some effects and local reactions, Ann. Geof., XXXVIII (5-6), 503-513.

Samardjieva, E., G. Payo and J. Badal (1997): Catalogue of Digital Historical Seismograms (1912-1962), in Wiechert Seismograph, Geophysical Observatory of Toledo (Instituto Geografico Nacional, Madrid), pp. 306

SÁNCHEZ NAVARRo-NeumanN, M.M. (1917): Ensayo sobre la sismicidad del suelo español, Boletín de la Real Sociedad de Historia Natural, 83-109.

SÁnchez NavarRo-NeumanN, M.M. (1920): Bosquejo sísmico de la Península Ibérica, La Estación Sismológica y el Observatorio Astronómico de Cartuja, Granada.

SilveIRA, D. (2002): Caracterização da sismicidade histórica dos Açores com base na re-interpretação de dados de macrosísmica: contribuição para a avaliação do risco Sísmico, M.Sc. Thesis (Universidade dos Açores).

Simões, J.Z. (2004): Catálogo Sísmico Aberto para Publicação na Internet, in Proceedings 3 a Assembleia LusoEspanhola de Geodesia e Geofísica, Figueira da Foz.

Sousa, M.L., A. Martins and C.S. Oliveira (1992): Compilação de ratálogos sísmicos da Região Ibérica, Laboratório Nacional de Engenharia Civil, Lisboa, Rep. 36/92-NDA, pp. 250.
SousA, M.L. and A. Martins (2000): Compilação de um Catálogo Sísmico para a Região dos Açores, Laboratório Nacional de Engenharia Civil, Lisboa, Proc. 260/18/13343

STUCCHI, M. (Editor) (1993): Historical Investigation of European Earthquakes, Materials of the CEC Project «Review of Historical Seismicity in Europe», vol. 1, pp. 258.

SuRIÑACH, E. and A. RocA (1982): Catálogo de Terremotos de Cataluña, Pirineos y zonas adyacentes, 1100-1979, Universidad Complutense, Cátedra de Geofísica, Publicación Técnica No.190, 9-106.

Susagna, T. and X. Goula (1999): Catàleg de Sismicitat, Atles Sísmic de Catalunya (Institut Cartogràfic de Catalunya, Barcelona), vol. I, pp. 436

Susagna, T., X. Goula and A. Roca (2001): A new macroseismic catalogue for Catalonia, in The Use of Historical Data in Natural Hazard Assessments, edited by T. Glade, P. Albini and F. Francès (Kluwer Academic Publishers), 71-79.

Susagna, T., A. Roca, X. Goula and J. Batlló (1993): Analysis of macroseismic and instrumental data for the study of the 19 November 1923 earthquake in the Aran Valley (Central Pyrenees), Natural Hazards, 10, 7-17.

Taramelli, T. and G. Mercalli (1886): Terremoti Andalusi cominciati il 25 diciembre 1884, Memoria Real Academia dei Lincei, vol. III, serie 4, 116-222.

TEIXIDOR Cros, J. (1884): Noticias de fenómenos volcánicos en Cataluña desde los tiempos prehistóricos, Memorias de la Real Academia de Ciencias Naturales y Artes de Barcelona, Tercera época, Tomo I, no. 8 .

WAGNER, M.N. (1993): Fontes para o estudo da sismicidade histórica do Algarve na primeira metade do século XVIII: a investigação no Archivo Nacional da Torre do Tombo, Lisboa, in Historical Investigation of European Earthquakes, Materials of the CEC Project «Review of Historical Seismicity in Europe», edited by M. STUCCHI (CNR, Milano), vol. 1, 207-224.

WAGNER, MN. L. Braga, B. Guerra and M.R T. BARATA (1993): Dados sobre sismos oorridos no estrangeiro e referidos em fontes existentes nos arquivos e bibliotecas portuguesas (séculos XVII e XVIII), in Historical Investigation of European Earthquakes, Materials of the CEC Project "Review of Historical Seismicity in Europe», edited by M. STUCCHI (CNR, Milano), vol. 1, 243-246. 